\title{
The Influence of Citizenship Norms, Efficacy Belief, and Parents' Participation on Students' Civic Engagement in Nigerian Universities: Data Screening and Preliminary Analysis
}

\author{
Ahmadu, Talatu Salihu \\ Awang Saleh Graduate School of Arts and Sciences, Universiti Utara Malaysia \\ 06010 Sintok, Kedah Darul Aman, Malaysia; Corresponding author: Tass2004@yahoo.com \\ Prof. Madya Dr. Yahya Bin Don \\ Awang Saleh Graduate School of Arts and Sciences, Universiti Utara Malaysia, 06010 Sintok \\ Kedah Darul Aman, Malaysia; Email:d.yahya@uum.edu.my

\section{Dr. Ismail Hussein Hamzat} \\ Awang Saleh Graduate School of Arts and Sciences, Universiti Utara Malaysia, 06010 Sintok \\ Kedah Darul Aman, Malaysia; Email:ihussein@uum.edu.my
}

\author{
Doi:10.5901/jesr.2016.v6n2p81
}

\section{Abstract}

This article explored the data collected regarding the influence of citizenship norms, efficacy belief, and parents' participation on students' civic engagement in Nigeria. Five hundred and eighty-four (584) students from eight universities located in northwest geopolitical zone of Nigeria completed a self administered questionnaire. The questionnaire is a 5- Likert-scale. The data was analyzed by means of Statistical Package for the Social Sciences (SPSS) package version 20. However, we conducted the initial screening and analysis of data so as to fulfil the assumptions specified for multivariate analysis. That is, the values missed out by respondents were treated. Then comes the assessment and handling of outliers, which are the disproportionate case scores that is expected to have a substantial negative impact on the outcomes. Following this, a test of normality, linearity and multicollinearity were performed. It was then concluded that the data was fit for further multivariate analysis..

Keywords: Citizenship Norms, Efficacy Belief, Parents' Participation, Students' Civic Engagement; Data Screening

\section{Introduction}

A preliminary screening of data is extremely vital in any multivariate analysis. This is because it helps researchers to recognize any possible violations of the main assumptions concerning the application of multivariate techniques of data analysis (Hair, Money, Samouel, \& Page, 2007). In addition, initial data screening makes researchers to comprehend the data collected better for further analysis. Until recently, some scholars (Hair, Black, Babin, \& Anderson, 2010) observed that scientific investigations have been conducted mostly without initial data screening and preliminary analysis perhaps due to the trouble attributed to it. Such oversight is a serious problem (Chernick,2008) because, overlooking of the initial data screening would increase the standard error estimates, which in turn influences the regression-based path coefficient negatively (Dijkstra, 1983; Ringle, Sarstedt, \& Straub, 2012).

Consequently, to fill in this practical gap, the present study intended at screening the data gathered on the effect of citizenship norms, efficacy beliefs, and parents' involvement on civil engagement among young university individuals in Nigeria. Afterwards, the data is subjected to check out the missed values for analysis, assessment of outliers, normality test, linearity and multicollinearity assessment as noted by (Tabachnick, \& Fidell, 2007; Hair et al., 2013). Given this, the article is structured under the following section: The early section focuses review of literature on the area under discussion. The next part highlighted how the methodology used in the present study was conducted, followed by the results offered in the other segment of the paper. While the last section draws conclusion on the findings of the study. 


\subsection{Literature Review}

\subsubsection{Civic Engagement}

Numerous factors have been studied to depict why citizens are involved in civic activities of the society. Some of the main factors include norms of citizenship, civic knowledge, self-efficacy, open classroom climate, volunteerism, pro-social values and activities, and political socialization (Dalton, 2008; Manganelli et al., 2014; Richardson, 2003; Campbell, 2008; Acharya et al., 2010a; Amnå, Ekström, Kerr, \& Stattin, 2009). Thus, civic engagement are those activities that focused people's attitudes, main beliefs, opinions, as well as behaviors that indicate the circumstances which are external to personal and communal networks (Amna, 2012). Although a review of civic engagement literature indicated that there is lack of agreement regarding, not only in the terminology used, and the different theoretical perspectives, but also the definitions offered are considered to be of a similar construct (Wilkenfeld, Lauckhardt, \& Torney- Purta, 2010). Despite the aforementioned empirical studies on these antecedents little is known on the links among norms of citizenship, parents' participation, efficacy beliefs, and youths' involvement in civil activities.

Since the factors responsible for people's involvement in civil activities is an outcome of their perception about good citizenship, the democracy theory (Thompson, 1970 ) is mainly helpful in illuminating the civic norms which resulted to participatory acts in various activism. Scholars like (Dalton, 2008; Theiss-Morse, \& Hibbing, 2005; Soja, Innocent, \& Abuh, 2014) have utilized the theory to elucidate the role of citizens in a democratic environment. Hence, established that the norms of citizenship have made people to become aware and get involved in both voluntary and civil activities as ways of performing their civic responsibility. In other words, a person's conviction (efficacy belief) is gradually affecting him to transform his culture so as to make life more habitable for the generality of people.

\subsubsection{Norms of Citizenship and Civic Engagement}

Educational psychologists have generally agreed that civic knowledge and norms, play an important role in promoting adolescents' expectations to participate in civic activities, such as voting, participating in a peaceful rally or march, and online discussion of politics(Galston, 2007; Manganelli, Lucidi, \& Alivernini, 2014; Torney-Purta, 2002). Norms of citizenship are the views held by citizens as what it meant for a person to be a good individual (Copeland, 2014). citizenship might shape the expectations of peoples' roles in civic and political processes. This is because citizenship identifies what is expected of the individual and what the individual expects of government, it influences a series of people's thinking and ultimately determine what prompted their actions in civil affairs (Kotzian,2014).

However, only a limited empirical research has investigated the role of citizenship norm as one of the vital factors that can promote young people's participation in civic activities. Such neglect has been unfortunate because to a greater extent, civic norm directly influences young adults' decisions whether to engage in or stay away from civic activities. Hence, civic norm is central to the accomplishment of civic engagement or participation. Although some researchers are divided on which citizenship norms (duty or engaged norms) is prominent. Contrarily, Dalton (2008) argued that citizenship norms explained that the notion people have about disengagement in civic activities is misconstrued. Thus, citizenship norms impact on people in different ways (Zaff, Malanchuk, \& Eccles, 2008).

\subsubsection{Parents' Participation}

In addition to norms of citizenship, parents' participation in civic activities is alleged to persuade young adults' decision to be engaged in schools' civic activities. Parents are seen to demonstrate as models in the process of socializing their offspring. Basically, children learn the dos and don'ts of their parents, which in turn affects their behaviour within the society at large. Children naturally seek to be accepted by their family and society (McClelland, 1987; Packer, 2008). Young adults who have a strong need for affiliation enjoy being part of a group and tend to conform to the group's norms in order to be accepted by other members of the group (Christensen, Rothgerber, Wood, \& Matz, 2004; McClelland, 1987; Packer, 2008; Smith \& Mackie, 2007; Smith, Hogg, Martin, \& Terry, 2007). Hence, it is reasonable to expect that youths' participation in civic activities could be shaped by their parents. Moreover, because of its theoretical importance, parents' real participation in civic activities has been suggested as an important predictor of youths' decision to engage in civic activities. However, only a few studies have examined the significant role of parents in determining youths' decision to engage in civic activities. 


\subsubsection{Efficacy Belief}

Relevant literatures also indicate that self-efficacy is a well-established factor that plays a significant role in understanding human behaviour because it shapes those opinions and actions they exhibited. Bandura, (2010) has pointed out that self- efficacy help to explain people's beliefs in their ability to influence events that affect their lives. Hence, a comprehensive review of literature in educational and social psychology suggests that self-efficacy influences various attitudinal and behavioural outcomes such as academic achievement(Burgoon, Meece, \& Granger, 2012; Caprara, Vecchione, Alessandri, Gerbino, \& Barbaranelli, 2011), health-related behaviours (French, 2013; Jones, Renger, \& Kang, 2007), and work-related performance (Judge, Jackson, Shaw, Scott, \& Rich, 2007; Sadri \& Robertson, 1993; Walumbwa, Lawler, Avolio, Peng Wang, \& Kan Shi, 2005).

However, only a handful of studies have explored the link between efficacy beliefs and civic engagement and or participation. Hence, this is another gap in the literature. Consequently, understanding the role of political efficacy (efficacy belief), the feeling that one's political action have, or can have, to influence the political process (Zmerli, 2010) in civic engagement is significant because (Morrell, 2005) explained that individuals who have soaring political efficacy are prone to engage in political participation, such as conversations that require them to argue before making conscious decision. In other words, efficacy beliefs predict changes in students' actual political attitudes and behaviours.

\section{Methodology}

\subsection{Sample}

Data was obtained from a sample of five hundred and eighty-four (584) students resulting in a response rate of $85 \%$. Young learners from eight (8) federal and state universities sited in the North-west Nigeria offered courses in citizenship education in line with the curriculum policy of University education. Universities were drawn using stratified probability sampling technique Ahmadu Bello University (ABU), Zaria; Kaduna State University (KSU) and Nigeria Defense Academy Kaduna. Kano University of Science and Technology Wudil (KUT); Bayero University are sited in kano state. Then comes Kebbi State University of Science and Technology Aliero; Umaru Musa Yar'adua University Katsina, with Usman Danfodio University Sokoto (UDUS) are among others.

\subsection{Sample Characteristics}

The characteristics examined are the gender, age, educational level of the respondents in university as well as the university type of the respondents. The responses obtained showed that of 584 participants, majority of the respondents in the sample; that is $394(67.5 \%)$ were males, while the remaining 190, representing $32.5 \%$ were females. Majority of participants 343 were above 26 years old (58.7\%) followed by 226 (38.7\%) students with age range between 21 to 25 years and the remaining $15(2.6 \%)$ were below 20 years of age. In terms of education a high proportion of the respondents $458(78.4 \%)$ students were in federal universities while $126(21.6 \%)$ were in state universities. A high proportion of the respondents comprised of 300 level students, which accounted for $386(66.1 \%)$ respondents. This is followed by 98 respondents (approximately 16.8\%) in 400 levels, while 91, representing 15.6\% were in 200 levels. The remaining 9 representing $1.5 \%$ were in 100 level.

\subsection{Measures}

We measured engaged citizenship norms using the subscale of Scheidegger and Staerkle (2011), a 5-item Likert scale ranging from 1 (strongly disagree) to 5 (strongly agree). Examples of item include "I partake in student union in order to influence civic decisions". On the other hand, we also measured duty-based citizenship norms using items adapted like "I always obey laws and regulations" from Citizenship, Involvement, Democracy Survey Howard, Gibson, \& Stolle, (2005), with 5-item Likert scale. While, efficacy belief was measured with adapted scale from Craig, Niemi, \& Silver, (1990), a five (5) item Likert which ranges from 1 - 5 respectively. "I know more about politics than most people my age" is an example of the items. The last instrument (civic engagement), was an 8-item scale adapted from Schulz \& Sibberns, (2004) such as" I vote in national election", and measured with a 5-Likert scale. 


\subsection{Technique}

We used Statistical Package for Social Sciences (SPSS) application software version 20 to screen the data collected for this study. The SPSS was developed by Nie \& Hull (1968) and is one of the most commonly used programs for statistical analysis in social science. However, this study adopted the SPSS because it is a complex method for analyzing data (Pallant, 2011). In other words, it performs multifarious manoeuvring of data as well as analysis with simple command. Besides, it accepts data from any sort of file and utilizes it for generating reports, providing features for plotting and presentation of results.

\section{Results and Discussion}

Prior to the data screening, we used the SPSS- Statistical Package for Social Sciences version 18.0. which was most popular for the task of cleaning data. Subsequently the screening commenced while centring on; missing value analysis; assessment of outliers; normality test, linearity and multicollinearity test as recommended by Hair et al., (2010). Hence, data must always be screened to ensure the data is reliable, as well as valid for testing the theory one intended to extend.

\subsection{Missing value analysis}

Out of the 27,133 data points, 52 had randomly missing values in the original SPSS dataset, which accounted for $0.19 \%$. In particular, engaged citizenship norms (ECNO3) and efficacy belief (EBO3) have 6 missing values each. Similarly engaged citizenship norms (ECN02 \& 5) have 5 missing values each; ECN02 \& duty citizenship norms (DCN03) have 4 missing values each; ECN01, ECN06, EB02, EB04, EB07, CVE05, CVE06, \& PP04 have 2 missing values each; EB06, EB09, CVE01, PP01, PP03,\& PP05 have 1 missing value each and no missing value was found in civic engagement (CVE03). There is no fixed percentage of missed values in a data set that makes a valid statistical inference. Some researchers like (Schafer, 1999; Tabachnick \& Fidell, 2007) have generally established that the rate of $5 \%$ or less of values missed is unimportant. Besides, researchers have recommended that the easiest way of replacing missing values is mean substitution if the total percentage of missing data is $5 \%$ or less (Little, \& Rubin, 1987; Raymond, 1986; Tabachnick, \& Fidell, 2007). Therefore, randomly missing values were replaced using mean substitution in this study, (Tabachnick, \& Fidell, 2007). Table 1 shows the total and percentage of randomly missing values in the present study.

Table 1. Result of Missing Values Identified and Replaced

\begin{tabular}{|c|c|c|}
\hline S/No & Result Variable & Number of Replaced Missing Values \\
\hline 1 & ECN01_1 & 2 \\
\hline 2 & ECNO2_1 & 5 \\
\hline 3 & ECNO3 1 & 6 \\
\hline 4 & ECNO4-1 & 4 \\
\hline 5 & ECN05_1 & 5 \\
\hline 6 & ECN06 1 & 2 \\
\hline 7 & DCNO3_1 & 4 \\
\hline 8 & EB02_i & 2 \\
\hline 9 & EB03_1 & 6 \\
\hline 10 & EB04_1 & 2 \\
\hline 11 & EB06_1 & 1 \\
\hline 12 & EB07_1 & 2 \\
\hline 13 & EB09_1 & 1 \\
\hline 14 & CVE01_1 & 1 \\
\hline 15 & CVE03_1 & $0^{a}$ \\
\hline 16 & CVE 051 & 2 \\
\hline 17 & CVE06_1 & 2 \\
\hline 18 & PP01_-1 & 1 \\
\hline 19 & PP03_1 & 1 \\
\hline
\end{tabular}




\begin{tabular}{ccc}
20 & PP04_1 & 2 \\
21 & PP05_1 & 1 \\
\hline & Total & 52 out of 27,133 data points \\
& Percentage & $0.19 \%$ \\
\hline
\end{tabular}

Note: Percentage of missing values is obtained by dividing the total number of randomly missing values for the entire data set by total number of data points multiplied by 100 .

\subsection{Assessment of outliers}

Another important procedure for data screening is the estimation and treatment of outliers. These are the extreme case scores that may probably have a considerable negative impact on the result of study (Barnett \& Lewis, 1994). Thus, the presence of outliers in the data set of a regression-based analysis can critically alter the estimates of regression coefficients which lead to results that are not reliable (Verardi, \& Croux, 2008). In order to distinguish any observation which seems to be outside the SPSS value labels as a result of incorrect data entry, first and foremost, frequency tables were tabulated for all variables using minimum and maximum statistics. Based on this initial analysis of frequency statistics, there was no any value discovered to be outside the normal range.

Consequently, we used Mahalanobis distance (D2) to inspect the multivariate outliers. Thus, some scholars like (Tabachnick \& Fidell 2007) have attested that Mahalanobis Distance (D2) helped in identifying and dealing with multivariate outlying cases. Based on thirty-four (34) observed variables of the study, the recommended threshold of chisquare is $65.25(p=0.001)$. Therefore, Mahalanobis values that exceeded this threshold were deleted. Given this criterion, forty-seven (47) multivariate outliers were recognised and subsequently deleted from the dataset. This is because the precision of data analysis technique might be affected. Consequently, after removing 47 multivariate outliers the final dataset in this study was 584 as depicted in Table 2.

Table 2. Multivariate Outliers Detected and Deleted

\begin{tabular}{|c|c|}
\hline Respondents Number & Mahalanobis Distance (D2) \\
\hline 1 & 66.78281 \\
\hline 2 & 76.82827 \\
\hline 14 & 69.44853 \\
\hline 16 & 67.64753 \\
\hline 41 & 76.36319 \\
\hline 45 & 81.06928 \\
\hline 55 & 73.88621 \\
\hline 63 & 68.36067 \\
\hline 69 & 81.22157 \\
\hline 77 & 74.31133 \\
\hline 95 & 98.25803 \\
\hline 97 & 80.05467 \\
\hline 111 & 75.5793 \\
\hline 113 & 99.78491 \\
\hline 125 & 68.71998 \\
\hline 149 & 90.81231 \\
\hline 153 & 82.44978 \\
\hline 158 & 66.28306 \\
\hline 161 & 99.25607 \\
\hline 190 & 72.0938 \\
\hline 200 & 104.31002 \\
\hline 201 & 65.99075 \\
\hline 210 & 67.06942 \\
\hline 222 & 75.0931 \\
\hline 226 & 66.34311 \\
\hline 240 & 80.31723 \\
\hline 260 & 68.6577 \\
\hline 288 & 75.85014 \\
\hline 319 & 93.12437 \\
\hline
\end{tabular}




\begin{tabular}{cc}
338 & 67.41406 \\
341 & 66.04293 \\
342 & 74.54885 \\
353 & 78.16664 \\
358 & 78.73422 \\
369 & 85.16338 \\
377 & 171.5105 \\
392 & 88.36981 \\
396 & 66.11589 \\
398 & 80.147 \\
417 & 71.62666 \\
423 & 71.01414 \\
472 & 68.99674 \\
481 & 74.77583 \\
518 & 68.76815 \\
523 & 80.00086 \\
527 & 67.91333 \\
539 & 67.64179 \\
\hline Note: $N=35 ;$ df $=34 ; X 2=65.25 ; p=0.001 ; D 2=\geq 65.25$
\end{tabular}

\subsection{Normality test}

Traditionally researchers like (Reinartz, Haenlein, \& Henseler, 2009; Wetzels, Odekerken-Schroder, \& Van Oppen, 2009) assumed that PLS-SEM provided accurate model estimations in situations that are extremely non-normal. Though, this postulation may turn out to be false. Hence, Hair, Sarstedt, Ringle \& Mena (2012) suggested that normality analysis should be done. Since, Tabachnick \& Fidell, (2007); Hair et al., (2010) argued that normality is essentially a way of making prediction in multivariate analysis. Chernick, (2008) clearly indicated that highly skewed or kurtoic data has the tendency of inflating the bootstrapped standard error estimates thus affecting the path coefficients as noted by Dijkstra, (1983) and Ringle et al., (2012). On this basis, the graphical method was used in this study to check for the normality of data collected (Tabachnick, \& Fidell, 2007).

It was suggested by Field, (2009) that in a large sample of 200 or more, it is more vital to look at the shape of the distribution graphically rather than looking at the value of skewness or kurtosis. Explaining further, Field, (2009) stated that a large sample reduces the standard errors; this in turn increases the value of the skewness and kurtosis statistics. Thus, this justified the reason for using graphical method of normality test rather than the statistical methods. In line with Field's (2009) proposition, a histogram and normal probability plots were examined to certify that normality assumptions have not been violated in this study. Figure 1 portrays the data in this study trail a normal pattern given that all the bars on the histogram seem like a normal curve. Thus, Figure 1 shows that normality assumptions have not been violated in the present study.

Histogram Dependent Variable: RespoNo

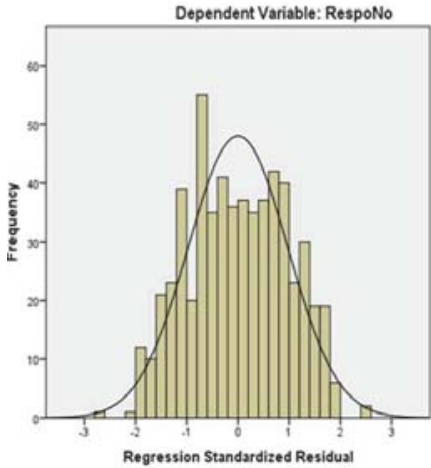

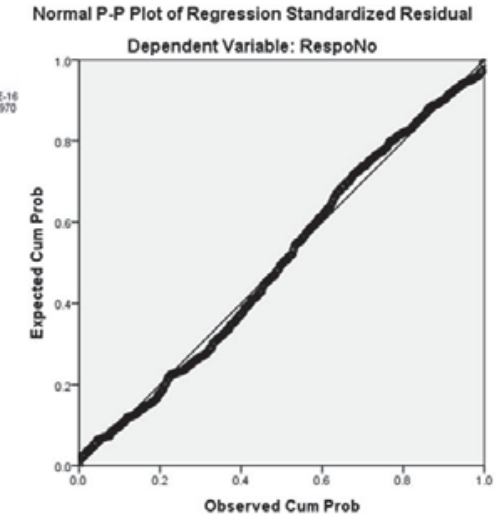

Figure 1 - Histogram and normal probability plots

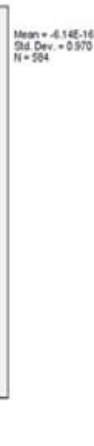




\subsection{Multicollinearity Test}

The occurrence of multicollinearity among the exogenous latent constructs according to Chatterjee, \& Yilmaz, (1992); and Hair, Black, Babin, Anderson, \& Tatham, (2006) can significantly alter the estimates of regression coefficients and their statistical significance tests. Multicollinearity means a situation in which one or more exogenous latent constructs turn out to be extremely correlated. Specifically, Tabachnick, \& Fidell, (2007) stated that multicollinearity increases the standard errors of the coefficients. This in turn makes the coefficients statistically not important. In order to notice multicollinearity, we employed two methods (Chatterjee, \& Yilmaz, 1992; Peng, \& Lai, 2012). In the first method, the correlation matrix of the exogenous latent constructs was examined. Therefore, a correlation coefficient of 0.90 and over indicates multicollinearity involving exogenous constructs (Hair, et al. 2010). Table 3 depicts the correlation matrix of all exogenous latent constructs.

Table 3. Correlation matrix of the exogenous latent constructs

\begin{tabular}{llccccc}
\hline Variables & $\mathbf{1}$ & $\mathbf{2}$ & $\mathbf{3}$ & $\mathbf{4}$ & $\mathbf{5}$ \\
\hline 1 & Engaged citizenship norms & 1 & & & & \\
2 & Duty citizenship norms & $.387^{*+}$ & 1 & & & \\
3 & Efficacy beliefs & $.339^{*+*}$ & $.437^{*+*}$ & 1 & & \\
4 & Parents' participation & $-.342^{* *}$ & $-.345^{* *}$ & $-.598^{*+*}$ & 1 & \\
5 & Civic engagement & $.376^{* *}$ & $.517^{* *}$ & $.466^{* *}$ & $-.437^{+*}$ & 1 \\
\hline
\end{tabular}

Note: Correlation is significant at the 0.01 level (1-tailed).

Table 3 indicated the correlations between the exogenous latent constructs which were amply under the recommended threshold values of 0.90 . This revealed that the exogenous constructs were independent as well as not extremely correlated. Thus, the indicators showed that they all have reached the satisfactory levels. Therefore, Hair, Ringle \& Sarstedt, (2011) reiterated that multicollinearity becomes a problem if VIF value is greater than 5 , tolerance value is smaller than 0.20 , and more than 30 in case of condition index. Table 4 depicts the level of tolerance values, VIF values and condition indices for the exogenous latent constructs.

Table 4. Tolerance and Variance Inflation Factors (VIF)

\begin{tabular}{lccc}
\hline \multirow{2}{*}{ Independent Variables } & \multicolumn{2}{c}{ Collinearity Statistics } & \multirow{2}{*}{ Condition Index } \\
& Tolerance & VIF & \\
\hline Engaged citizenship norms & .794 & 1.260 & 6.288 \\
Duty citizenship norms & .741 & 1.349 & 13.151 \\
Efficacy beliefs & .577 & 1.732 & 16.403 \\
Parents' participation & .618 & 1.618 & 28.818 \\
\hline
\end{tabular}

However, It can be deduced from what obtains on table 4 that all the exogenous latent constructs are not extremely correlated. Besides, the tolerance values is greater than 0.20 . While, the VIF are well below .5 with condition indices lower than 30 (Hair et al., 2014). As a result, the indicators showed no any signal to Collinearity problem.

\subsection{Linearity}

Linearity postulation indicates that a straight-line connection prevails between the independent and dependent variables. Linearity is assessed by evaluating the shape of the scatteplots within the scatterplots matrices. Linearity assumption is typically examined through the scatterplots of each exogenous constructs with the endogenous construct or partial correlation plots between both independent and the dependent constructs. According to Mertler \& Vannata, (2010), the shape of the scatterplots should be elliptical thus substantiates the assumption of linearity (Hair et al., 2010).

\section{Conclusion}

Several empirical studies have been carried out with little or no concern for data screening and preliminary analysis. However, disregarding such initial data screening may spell doom for the multivariate analysis, consequently, inflating the 
estimated standard error, for that reason, this study was presented to make known the implication of critical component of multivariate analysis. Furthermore, it is vital to state that ensuring proper screening of data before the commencement of multivariate analysis provides better insight to what obtains in the data. To put simply, when the researcher accurately examines as well as treats the values missing, identifies outliers, normal data distribution with multicollinearity then the task in analysis is half done. Bearing this in mind, it is evident that the preliminary assumptions of multivariate analysis were not debased in this study. Thus, it can be said without doubt that the data was fit for further multivariate analyses, the assessment of the measurement model as well as model structure.

\section{References}

Acharya, R., Singh, A., Santhya, K., Ram, F., Jejeebhoy, S., Ram, U., \& Mohanty, S.(2010a). Participation in civil society and political life among young people in Maharashtra: Findings from the Youth in India-Situation and Needs study. Journal of adolescence, 33(4), 553-561.

Aghedo, I., \& Osumah, O. (2012). The Boko Haram Uprising: How Should Nigeria Respond? Third world quarterly, 33(5), $853-869$.

Amnå, E., Ekström, M., Kerr, M., \& Stattin, H. (2009). Political socialization and human agency: The development of civic engagement from adolescence to adulthood. Statsvetenskaplig tidskrift, 111(1).

Amnå, E. (2012). How is civic engagement developed over time? Emerging answers from a multidisciplinary field. Journal of adolescence, 35(3), 611-627.

Bandura, A. (2010). Self-Efficacy The Corsini Encyclopedia of Psychology: John Wiley \& Sons, Inc.

Barnett, V., \& Lewis, T. (1994). Outliers in statistical data. New York: Wiley.

Berger, B. (2009). Political theory, political science and the end of civic engagement. Perspectives on Politics, 7(02), 335-350.

Burgoon, J. M., Meece, J. L., \& Granger, N. A. (2012). Self-efficacy's influence on student academic achievement in the medical anatomy curriculum. Anatomical Sciences Education, 5(5), 249-255.

Campbell, D. E. (2008). Voice in the classroom: How an open classroom climate fosters political engagement among adolescents. Political Behavior, 30(4), 437-454.

Caprara, G. V., Vecchione, M., Alessandri, G., Gerbino, M., \& Barbaranelli, C. (2011). The contribution of personality traits and selfefficacy beliefs to academic achievement: A longitudinal study. British Journal of Educational Psychology, 81(1), 78-96.

Chatterjee, S., \& Yilmaz, M. (1992). A Review of regression diagnostics for behavioral research. Applied Psychological Measurement, $16,209-227$.

Chernick, M. R. (2008). Bootstrap methods. A guide for practitioners and researchers (2nd ed.). Hoboken, New Jersey: John Wiley \& Sons, Inc.

Christensen, P. N., Rothgerber, H., Wood, W., \& Matz, D. C. (2004). Social norms and Identity relevance: A motivational approach to normative behaviour. Personality and Social Psychology Bulletin, 30, 1295-1309.

Copeland, L. (2014). Conceptualizing political consumerism: How citizenship norms differentiate boycotting from buycotting. Political studies, 62(S1), 172-186.

Craig, S. C., Niemi, R. G., \& Silver, G. E. (1990). Political efficacy and trust: A report on the NES pilot study items. Political Behavior, 12(3), 289-314.

Cunningham, F. (2002). Theories of democracy: a critical introduction: Cambridge University Press.

Dalton, R. J. (2008). Citizenship norms and the expansion of political participation. Political studies, 56(1), 76-98.

Dijkstra,T. (1983). Some comments on maximum likelihood and partial least squares methods. Journal of Econometrics, 22(1-2), 67-90.

Djurkovic, N., McCormack, D., \& Casimir, G. (2008). Workplace bullying and intention to leave: the moderating effect of perceived organizational support. Human Resource Management Journal, 18, 405-422.

Field, A. (2009). Discovering Statistics using SPSS (3rd ed.). London: Sage Publications.

French, D. P. (2013). The role of self-efficacy in changing health-related behaviour: Cause, effect or spurious association? British Journal of Health Psychology, 18(2), 237-243.

Galston, W. A. (2007). Civic Knowledge, Civic Education, and Civic Engagement: A Summary of Recent Research. International Journal of Public Administration, 30(6-7), 623-642.

Hair, J. F., Black, W. C., Babin, B. J., \& Anderson, R. E. (2010). Multivariate data analysis. (7th ed.). Upper Saddle River, New Jersey: Prentice Hall.

Hair, J. F., Black, W. C., Babin, B. J., Anderson, R. E., \& Tatham, R. L. (2006). Multivariate data analysis (6th ed.). Upper Saddle River, NJ: Pearson/Prentice Hall.

Hair, J. F., Anderson, R. E., Tatham, R. L., \& Black, W. (1998). Multivariate data analysis, Upper Saddle River.

Hair, J. F., Money, A. H., Samouel, P., \& Page, M. (2007). Research method for business. West Sussex, England: John Wiley \& Sons Ltd.

Hair, J. F., Ringle, C. M., \& Sarstedt, M. (2011). PLS-SEM: Indeed a Silver Bullet. Journal of Marketing Theory and Practice, 18, 139152.

Hair, J. F., Sarstedt, M., Ringle, C. M., \& Mena, J. A. (2012). An assessment of the use of partial least squares structural equation modelling in marketing research. Journal of the Academy of Marketing Science, 40, 414-433.

Hair, J. F., Hult, G. T. M., Ringle, C. M., \& Sarstedt, M. (2014). A Primer on Partial Least Squares Structural Equation Modelling. (PLS- 
SEM). Thousand Oaks: Sage.

Howard, M. M., Gibson, J. L., \& Stolle, D. (2005). The US citizenship, involvement, democracy survey. Centre for Democracy and Civil Society (CDACS), Georgetown University.

Jones, E. G., Renger, R., \& Kang, Y. (2007). Self-efficacy for health-related behaviours Among deaf adults. Research in Nursing \& Health, 30(2), 185-192.

Judge, T. A., Jackson, C. L., Shaw, J. C., Scott, B. A., \& Rich, B. L. (2007). Self-efficacy and work-related performance: the integral role of individual differences. Journal of Applied Psychology, 92(1), 107.

Krejcie, R. V., \& Morgan, D. W. (1970). Determining sample size for research activities. Educational and Psychological Measurement, $30,607-610$

Kotzian, P. (2014). Good Governance and Norms of Citizenship: An Investigation into the System-and Individual-Level Determinants of Attachment to Civic Norms. American Journal of Economics and Sociology, 73(1), 58-83

Little, R. J. A., \& Rubin, D. B. (1987). Statistical Analysis with Missing Data. New York: John Wiley \& Sons, Inc.

Manganelli, S., Lucidi, F., \& Alivernini, F. (2014). Adolescents' expected civic participation: The role of civic knowledge and efficacy beliefs. Journal of adolescence, 37(5), 632-641.

McClelland, D. C. (1987). Human Motivation. Cambridge: Cambridge University Press.

Morrell, M. E. (2005). Deliberation, democratic decision-making and internal political efficacy. Political Behavior, 27(1), 49-69.

National Universities Commission (NUC) (2013).Student enrollment 2012/2013 Abuja: NUC.

Nie, N. H., Hull, C. H., Jenkins, J. G., Steinbrenner, K., \& Bent, D. H. (1975). SPSS: Statistical package for the social sciences.McGrawHill. New York, 353

Onuoha, F. C. (2010). The islamist challenge: Nigeria's Boko Haram crisis explained. African Security Review, 19(2), 54-67.

Packer, D. J. (2008). On being both with us and against us: A normative conflict model of dissent in social groups. Personality and Social Psychology Review, 12(1), 50-72.

Pallant, J. (2011). SPSS Survival Manual: A step by step guide to data analysis using SPSS for windows (3rd ed.). England: McGraw Hill Open University Press.

Peng, D. X., \& Lai, F. (2012). Using partial least squares in operations management research: A practical guideline and summary of past research. Journal of Operations Management, 30(6), 467-480.

Raymond, M. R. (1986). Missing data in evaluation research. Evaluation \& the Health Professions, 9, 395-420.

Reinartz, W. J., Haenlein, M., \& Henseler, J. (2009). An empirical comparison of the efficacy of covariance based and variance-based SEM. International Journal of Research in Marketing, 26, 332-344.

Richardson, W. K. (2003). Connecting political discussion to civic engagement: The role of civic knowledge, efficacy and context for adolescents.

Ringle, C. M., Sarstedt, M., \& Straub, D. W. (2012). A Critical Look at the Use of PLS-SEM in MIS Quarterly. MIS Quarterly, 36(1), iii-xiv.

Sadri, G., \& Robertson, I. T. (1993). Self-efficacy and Work-related Behaviour: A Review and Meta-analysis. Applied Psychology, 42(2), 139-152.

Scheidegger, R. \& Staerklé, C. (2011), Political Trust and Distrust in Switzerland: A Normative Analysis. Swiss Political Science Review, 17: $164-187$

Schulz, W., \& Sibberns, H. (2004). IEA civic education study: Technical report.

Sekaran, U., \& Bougie, R. (2010). Research Methods for Business: A Skill Building Approach: John Wiley \& Sons.

Smith, E. R., \& Mackie, D. M. (2007). Social psychology (3rd ed.). Philadelphia: Psychology Press.

Smith, J. R., Hogg, M. A., Martin, R., \& Terry, D. J. (2007). Uncertainty and the influence of group norms in the attitude-behaviour relationship. British Journal of Social Psychology, 46, 769-792.

Soja, J. Y., Innocent, A. P., \& Abuh A. P. (2014). Citizenship Education and Democratic Stability in Nigeria. International Journal of Peace and Conflict Studies (IJPCS), 2(1), 46-49.

Tabachnick, B. G., \& Fidell, L. S. (2007). Using multivariate statistics (5th ed.). Boston: Allyn and Bacon.

Theiss-Morse, E., \& Hibbing, J. R. (2005). Citizenship and civic engagement. Annu. Rev. Polit. Sci., 8, 227-249.

Thompson, D. F. (1970). The democratic citizen: University Press.

Torney-Purta, J. (2002). The School's Role in Developing Civic Engagement: A Study of Adolescents in Twenty-Eight Countries. Applied Developmental Science, 6(4), 203-212

Verardi, V., \& Croux, C. (2008). Robust regression in Stata. Available at SSRN 1369144.

Wilkenfeld, B., Lauckhardt, J., \& Torney-Purta, J. (2010). The relation between developmental theory and measures of civic engagement in research on adolescents. Handbook of research on civic engagement in youth, 193-220.

Walumbwa, F. O., Lawler, J. J., Avolio, B. J., Peng Wang, \& Kan Shi. (2005). Transformational Leadership and Work-Related Attitudes: The Moderating Effects of Collective and Self-Efficacy Across Cultures. Journal of Leadership \& Organizational Studies, 11(3), 216.

Wetzels, M., Odekerken-Schroder, G., \& Van Oppen, C. (2009). Using PLS path modelling for assessing hierarchical construct models: guidelines and empirical illustration. MIS Quarterly, 33, 177-195.

Zaff, J. F., Malanchuk, O., \& Eccles, J. S. (2008). Predicting positive citizenship from adolescence to young adulthood: The effects of a civic context. Applied Development Science, 12(1), 38-53. 
